\title{
Fern Distortion Syndrome of Leatherleaf Fern in Costa Rica: Symptoms, Incidence, and Severity
}

J. W. Kloepper, Department of Entomology and Plant Pathology, Auburn University, Auburn, AL 36894; F. Saborío, Centro de Investigaciones Agronómicas, Universidad de Costa Rica, San José, Costa Rica; E. Bustamante, CATIE, 7170 Turrialba, Costa Rica; J. E. Polston, Department of Plant Pathology, University of Florida, Gainesville 32611; E. Sánchez, Centro de Investigación en Estructuras Microscópicas (CIEMíc), Universidad de Costa Rica, San Pedro de Montes de Oca, San José, Costa Rica; and G. Umaña, Laboratorio de Tecnología Poscosecha, Centro de Investigaciones Agronómicas, Universidad de Costa Rica, San José, Costa Rica

\begin{abstract}
Kloepper, J. W., Saborío, F., Bustamante, E., Polston, J. E., Sánchez, E., and Umaña, G. 2010. Fern distortion syndrome of leatherleaf fern in Costa Rica: Symptoms, incidence, and severity. Plant Dis. 94:940-951.

A syndrome has been recognized on leatherleaf fern (Rumohra adiantiformis) in Costa Rica for many years that causes widespread damage but has not been described in the literature. A full description of the syndrome, termed fern distortion syndrome (FDS), is reported here, along with evidence that FDS is a new disease and that it is associated with endophytic fluorescent pseudomonads but not with any other major groups of pathogens or pests. The main aboveground symptoms of FDS are twisting and distortions of fronds, which make the fronds unmarketable. In advanced cases of FDS, fronds are often thickened, new frond growth ceases or slows dramatically, and uneven sporulation is apparent on the underside of fronds. Symptoms of FDS belowground are reduced diameter of rhizomes and reduced overall root mass. The incidence of FDS in Costa Rica was typically over $80 \%$, and severity typically ranged from 1.26 to 2.48 using a 0 to 3 rating scale in fields propagated vegetatively with rhizomes from fields with FDS. In contrast, in three fields planted 1.5 to 4 years previously with rhizomes derived from tissue culture, incidence and severity were markedly lower: 23 to $34 \%$ and 0.24 to 0.36 , respectively. Paired sampling of symptomatic and asymptomatic plants revealed significantly greater populations of fluorescent pseudomonads inside rhizomes of symptomatic plants.
\end{abstract}

Leatherleaf fern (Rumohra adiantiformis) is grown in several tropical and semitropical regions of the world. Production in the United States is confined to Florida (13). After being cut, the fronds can be stored for 1 month at $4^{\circ} \mathrm{C}$ and still last over 10 days in a vase (13). This feature, together with the highly symmetrical triangular shape of fronds and dark green color, makes leatherleaf fern the most common fern in cut flower arrangements (4).

In Costa Rica, nontraditional agricultural export products, including leatherleaf fern, were promoted by governmental policies following a regional economic crisis in the 1980s (11). By 1998, cultivation of leatherleaf fern in Costa Rica was reported on 1,458 ha (14). The value of

Corresponding author: J. W. Kloepper

E-mail: kloepjw@auburn.edu

Accepted for publication 15 April 2010.

doi:10.1094/PDIS-94-8-0940

(C) 2010 The American Phytopathological Society foliage plant exports, dominated by leatherleaf fern, increased from $\$ 9$ million in 1988 to \$31 million in 1993 (3).

In the mid-1990s, growers in Costa Rica began noticing increased incidence of fronds with irregular shapes. After being cut in the ferneries, fronds are taken to a packing facility where each frond is sorted for export. Fronds with minor irregularities in shape fall into a lower quality and price grade, and those with severe sporulation and moderate to severe distortions are discarded as culls. Severe sporulation is characterized by the presence of brown to black colored spores and results in shedding of spores in flower arrangements, which is considered an indicator of poorquality fronds. By the end of the 1990s, the frequency of deformed fronds had increased, and correspondingly the volume of culled fronds increased throughout Costa Rica. From 1998 to 2002, there was a $52 \%$ decrease in production measured in bundles of marketable fronds per hectare per year (6). During the same time period, the export volume for the country in the high season dropped from three shipping containers per week to one (6).
From 1997 to 2003, many studies were conducted by university researchers, agricultural consultants, and agronomists in charge of fern production at individual ferneries in attempts to find reasons for the decreased production of high-quality fronds and to develop optimized production practices to minimize losses (F. Saborío and E. Bustamante, unpublished). These studies included analysis of soil physical and chemical properties, studies on plant nutrition and insect and nematode populations, and searches for pathogens such as fungi, bacteria, viruses, and other microscopic organisms. However, it was not possible to find a cause that was specifically associated with the observed symptoms. Further, attempts to manage the disease by use of fungicides, nematicides, and insecticides were not successful, although some ferneries reported reduction in symptoms following sprays with tetracycline. None of these studies has been published, making it difficult to understand the overall scope of the syndrome or even its specific symptoms. For example, this syndrome has been referred to by several names, including vena roja (red vein), vena amarilla (4) (yellow vein), and mongolismo (severe dwarfing and stunting) (16). One of the most common names given to this syndrome has been Mal de Sterlof.

From growers' experiences with trying to manage fern distortions, it is generally accepted that the syndrome is transmitted to new production areas via vegetative propagules (rhizomes), mainly when roots and soil are carried from an older production field. Since propagation of leatherleaf fern relies mainly on this method, there is a potential for increase of the syndrome over time. However, determining the role of rhizomes in fern distortion requires analysis of the incidence and severity of the disease, which in turn are dependent upon a clear disease description and a rating system.

Hence, the overall aim of this study was to begin clarifying the situation with fern distortions in Costa Rica. Toward this aim, in this manuscript a new disease, fern dis- 
tortion syndrome (FDS), is described, and results of a survey on the incidence and severity of the disease in Costa Rica are reported. In addition, results are summarized of multiple research projects conducted from 1998 to 2004 that reported the inability to associate FDS with any one specific pathogen. Finally, new studies testing the hypothesis that FDS is related to populations of endophytic fluorescent pseudomonads inside rhizomes are presented. A portion of this work was previously reported in abstract form (8).

\section{MATERIALS AND METHODS}

Description of FDS. Observations of ferns reported by growers as being damaged have been made annually since 1997 . These on-farm observations were made at more than 30 different ferneries throughout all fern-growing climatic zones in Costa Rica. The most common symptoms observed and reported by growers were recorded.

Development of a rating system for FDS. In 2005, a 4-point rating system (0 to 3) was developed based on how severely distorted the fronds appeared, because frond distortion was the most ubiquitous symptom of FDS. With this scale, 0 indicates normal appearance with symmetrical frond; 1 indicates slight distortion of frond shape with bending of frond tip or some twisting of the frond rachis; 2 indicates more severe distortion of frond shape with clear asymmetrical shape overall and specifically a distorted appearance of the frond tip; and 3 indicates severe twisting of rachis and loss of triangular shape of frond (Fig. 1).

Relation of frond distortion to underground symptoms. In 2005, a sampling protocol was designed to determine if reduced growth of rhizomes and roots were symptoms of FDS, as frequently reported by growers. Five commercial ferneries were selected, one in each of the following five growing regions: Poasito (higher elevations of Poás Volcano), Poás (lower elevations of Poás Volcano), Grecia (Alajuela Province), Tucurrique (Cartago Province), and Sarchí (Alajuela Province). At each location, paired sampling was performed by collecting rhizomes from which were growing fronds with or without FDS symptoms. Ten locations for sampling at each fernery were randomly selected by walking down every third row starting 10 rows into the fernery. At each sampling location, the closest fern plant that had no symptoms and the closest one that showed distortions of the youngest fully emerged frond were selected. The rhizome attached to each frond was removed, along with attached roots, and bagged. The diameter of each rhizome was measured at a point 3 $\mathrm{cm}$ distal from the growing tip. Afterward, a 5-cm-long piece of rhizome was cut, beginning at the measurement point, and all roots attached to the rhizome piece
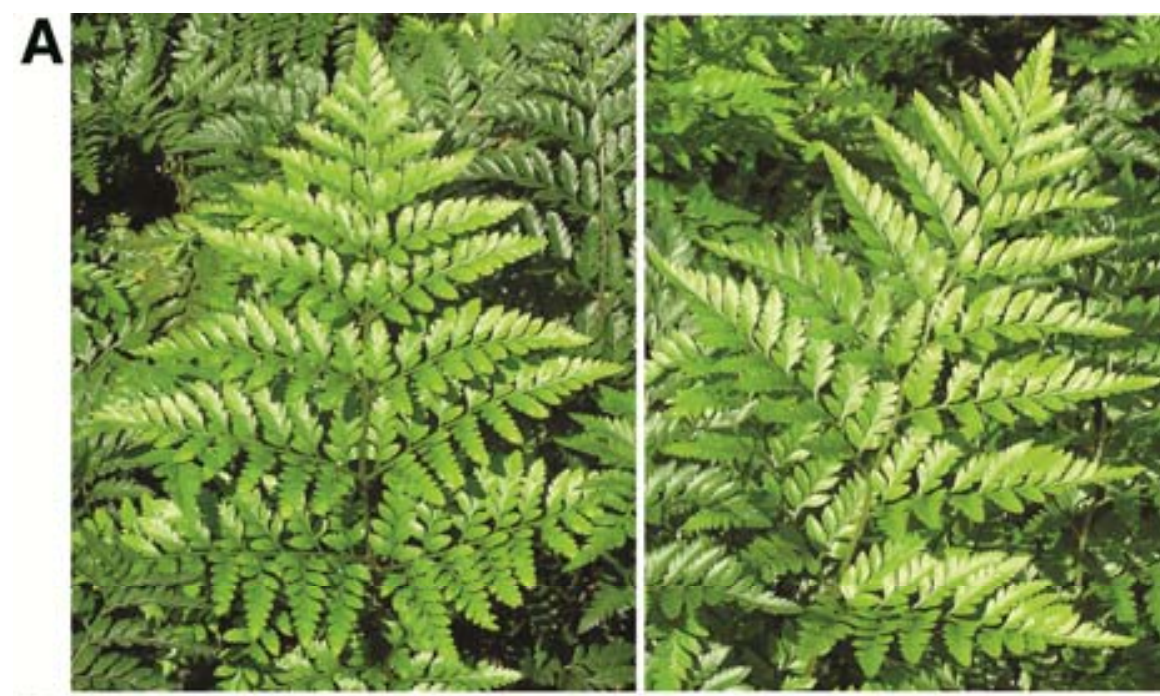

B
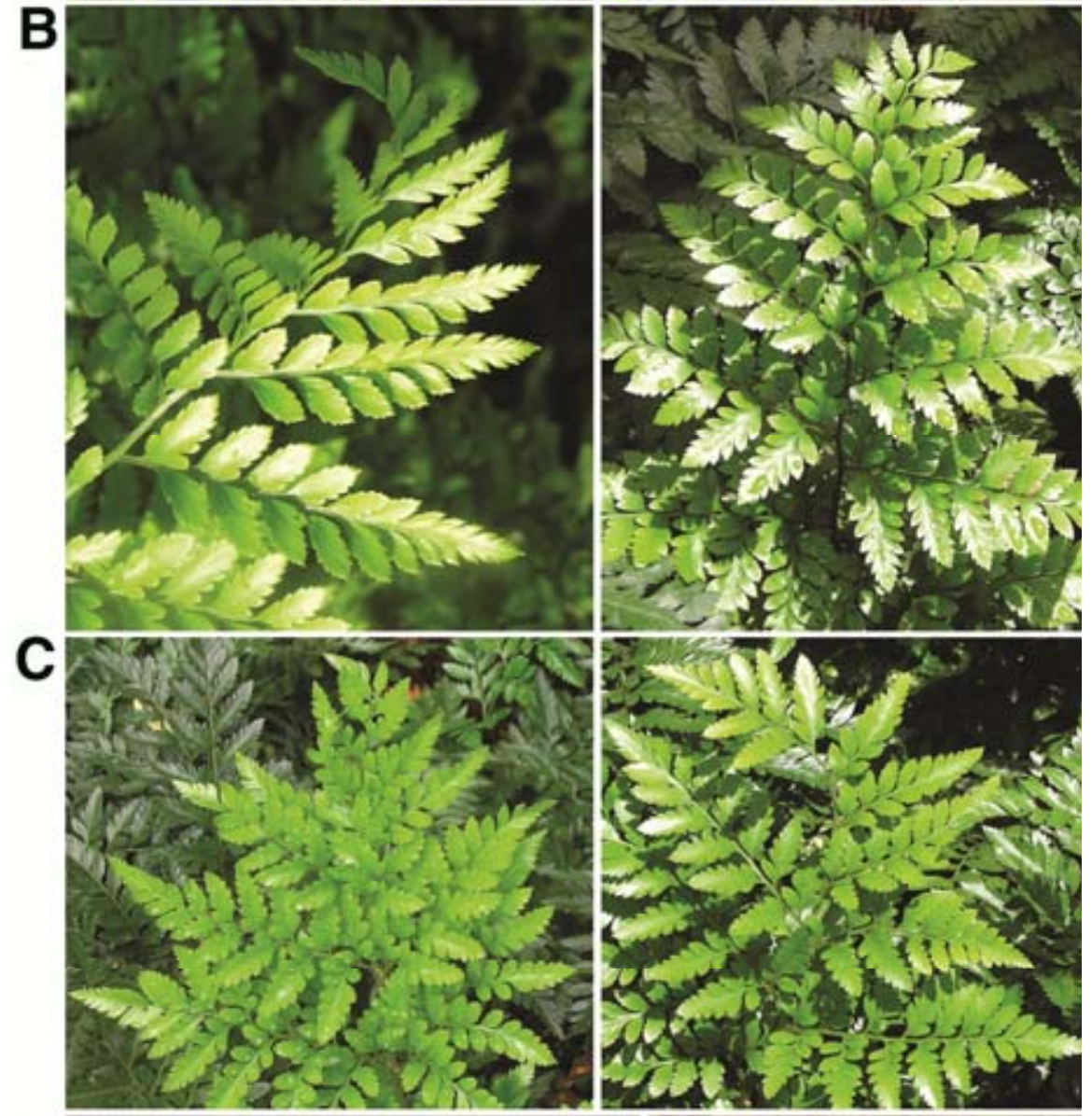

D

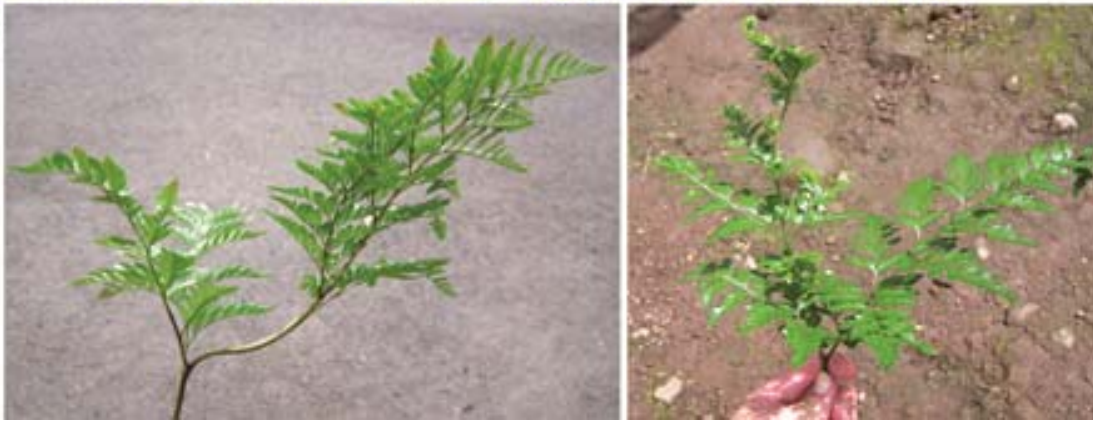

Fig. 1. Rating system for fern distortion syndrome: A, rating 0 , healthy; $\mathbf{B}$, rating 1 , slightly damaged; C, rating 2 , moderately damaged; $\mathbf{D}$, rating 3 , severely damaged. 
were cut and weighed. Hence, at each fernery, paired sampling was done using 10 replicate samples that were collected and processed from symptomatic and asymptomatic ferns. The data from each pair were analyzed by ANOVA using SAS (SAS Institute, Cary, NC). When a significant $F$ value was determined, LSD values were calculated at $P=0.05$ and 0.01 .

During the processing of rhizomes described above, an internal discoloration of the vascular region was observed in many rhizomes from distorted fronds. Subsequently, the rhizomes collected in the paired sampling from Poás and Poasito regions were cut longitudinally, and the presence or absence of vascular discoloration was noted. Isolations were performed from 10 rhizomes with and 10 without discoloration by first recutting rhizomes with a scalpel soaked for $1 \mathrm{~min}$ in $70 \%$ ethanol, flamed, and cooled, and then probing the discolored area with a sterile loop and plating onto King's B medium agar plates for detection of fluorescent pseudomonads and onto plates of water agar and potato dextrose agar (PDA) for fungi. Presence or absence of fluorescent bacterial colonies was noted after incubation for $48 \mathrm{~h}$ at $28^{\circ} \mathrm{C}$, and the presence or absence of fungi was noted after incubation for 10 days at room temperature.

Testing the association of pathogens with FDS. As noted above, many studies were conducted from 1997 to 2003 to find the causal agent of FDS. Among these tests were the following:

Field isolations for pathogens. On several visits to different ferneries, samples were taken from leaves, rachises, rhizomes, and roots with initial, intermediate, or advanced symptoms of FDS. Samples from damaged tissue were disinfected for 1 min in $1 \%$ sodium hypochlorite and then rinsed 3 times in sterile water. Then from the advance region of the lesion (frond, rachis, or rhizome), a section was taken and cultured on PDA, water agar, and nutrient agar plates. The plates were incubated at $21 \pm 2^{\circ} \mathrm{C}$.

Electron microscopy. Samples from pinnae, rachises, rhizomes, and roots of plants with and without symptoms of FDS were collected from ferneries in Cartago, Heredia, and Alajuela and observed under transmission and scanning electron microscopy.

For scanning microscopy, the samples collected were of approximately $1 \mathrm{~cm}^{2}$. They were fixed on a solution of glutaraldehyde $(2.5 \%)$, paraformaldehyde $(2 \%)$, and a sodium phosphate buffer $(0.1 \mathrm{M}$ at $\mathrm{pH}$ 7.4) for $2 \mathrm{~h}$. The samples were then rinsed 3 times using the same buffer and postfixed with $1 \%$ osmium tetroxide for 1 h. Samples were then rinsed 3 times with distilled water, placed in $25 \%$ dimethyl sulfoxide, and then on $50 \%$ dimethyl sulfoxide. The samples were cryofractured using liquid nitrogen and washed several times with distilled water. Then samples were dehydrated using an ethanol gradient $(30,50,70,90$, and $95 \%$, and two times on $100 \%$ ), followed by four changes in terbutanol, and drying by sublimation (Sublimator VF-20). Samples were then mounted on aluminum bases using double-sided tape and covered with 300-nm gold particles using Giko ID-2. The samples were observed with a Hitachi H-S 570 scanning electron microscope.

For transmission electron microscopy, two 3-mm pieces of each of the collected samples were fixed and postfixed using the same protocol described for scanning microscopy. The samples were dehydrated using an acetone gradient $(30,50,70$, and $90 \%$, and three times on $100 \%$ ). The samples were then infiltrated using Spurr resin by transferring the samples first to acetone:resin (1:1) solution and then to $100 \%$ resin. Inclusion and polymerization of the resin was done at $60^{\circ} \mathrm{C}$ for $12 \mathrm{~h}$. Ultrafine sections (70 to $90 \mu \mathrm{m}$ ) were done using the Reichert ultramicrotome (Reichert Ultracut-Leica). The samples were immediately contrasted with uranyl acetate (4\% in ethanol) and lead hydroxide. The samples were observed on a Hitachi H-7100 transmission electron microscope.

Detection of viruses. Multiple assays were conducted to determine if one or more viruses were associated with FDS symptomatic ferns. Samples of rhizomes

Table 1. Survey of ferneries to determine incidence and severity of fern distortion syndrome

\begin{tabular}{|c|c|c|c|c|c|c|c|c|c|}
\hline \multirow{2}{*}{$\begin{array}{l}\text { Site } \\
\text { no. }\end{array}$} & \multirow[b]{2}{*}{ Region } & \multirow{2}{*}{$\begin{array}{l}\text { Fernery, } \\
\text { section }^{c}\end{array}$} & \multicolumn{3}{|c|}{ Incidence $^{\mathrm{a}}$ per block $(\%)$} & \multicolumn{3}{|c|}{ Severity ${ }^{b}$ per block } & \multirow{2}{*}{$\begin{array}{l}\text { Rhizome source, standard } \\
\text { or unique practices }\end{array}$} \\
\hline & & & Block $^{\mathbf{d}} \mathbf{1}$ & Block 2 & Meand $^{d}$ & Block 1 & Block 2 & Mean & \\
\hline 1 & Poasito & A, 7 & 96 & 96 & 96 & 2.30 & 2.66 & 2.48 & On-farm rhizomes, standard \\
\hline 2 & Poás & $\mathrm{B}, 1$ & 66 & 62 & 64 & 0.78 & 0.74 & 0.67 & On-farm rhizomes, solarizede 1 yr ago \\
\hline 3 & Poás & B, 29 & 98 & 96 & 97 & 2.30 & 2.18 & 2.24 & On-farm rhizomes, standard \\
\hline 5 & Poás & $\mathrm{C}, 2$ & 98 & 92 & 95 & 2.14 & 1.78 & 1.96 & On-farm rhizomes, standard \\
\hline 6 & Poás & $\mathrm{D}, 2$ & 84 & 86 & 85 & 1.46 & 1.62 & 1.54 & On-farm rhizomes, standard \\
\hline 7 & Poás & $\mathrm{D}, 40$ & 90 & 88 & 89 & 1.94 & 1.86 & 1.90 & On-farm rhizomes, standard \\
\hline 8 & Poás & $\mathrm{E}, 2$ & 88 & 84 & 86 & 1.74 & 1.58 & 1.66 & On-farm rhizomes, standard \\
\hline 9 & Poás & $\mathrm{F}, 1$ & 94 & 96 & 95 & 1.50 & 1.51 & 1.51 & On-farm rhizomes, standard \\
\hline 10 & Grecia & $\mathrm{G}, 1$ & 88 & 90 & 89 & 1.48 & 1.26 & 1.37 & On-farm rhizomes, standard \\
\hline 11 & Cartago & $\mathrm{H}, 12$ & 94 & 92 & 93 & 1.74 & 1.80 & 1.77 & On-farm rhizomes, standard \\
\hline 12 & Irazú & I, 20 & 96 & 98 & 97 & 1.68 & 1.50 & 1.59 & On-farm rhizomes, standard \\
\hline 13 & Irazú & $\mathrm{J}, 2$ & 78 & 78 & 78 & 1.04 & 1.18 & 1.11 & On-farm rhizomes, renovated ${ }^{\mathrm{f}} 1 \mathrm{yr}$ ago \\
\hline 14 & Irazú & $\mathrm{K}, 10$ & 90 & 88 & 89 & 1.40 & 1.20 & 1.30 & On-farm rhizomes, standard \\
\hline 15 & Irazú & $\mathrm{K}, 12$ & 96 & 98 & 97 & 1.94 & 1.92 & 1.93 & On-farm rhizomes, standard \\
\hline 16 & Irazúg $^{g}$ & $\mathrm{~K}, 26$ & & & 23 & & & 0.24 & $\begin{array}{l}\text { Planted } 1.5 \text { yr ago with rhizomes from } \\
\text { tissue culture }\end{array}$ \\
\hline 17 & Irazúg & K, 28 & & & 34 & & & 0.36 & $\begin{array}{l}\text { Planted } 3 \text { yr ago with rhizomes from } \\
\text { tissue culture }\end{array}$ \\
\hline 18 & Sarchíg & $\mathrm{L}, 2 \mathrm{~A}$ & & & 25 & & & 0.25 & $\begin{array}{l}\text { Planted } 4 \text { yr ago with rhizomes from } \\
\text { tissue culture }\end{array}$ \\
\hline 19 & Sarchíg & $\mathrm{L}, 2 \mathrm{~B}$ & & & 87 & & & 1.40 & On-farm rhizomes, standard \\
\hline 20 & Sarchí & M, 67 & 88 & 94 & 91 & 1.30 & 1.22 & 1.26 & On-farm rhizomes, standard \\
\hline 21 & Sarchí & $\mathrm{N}, 110$ & 90 & 94 & 92 & 1.80 & 1.74 & 1.77 & On-farm rhizomes, standard \\
\hline 22 & Tucurrique & $\mathrm{O}, 3$ & 92 & 88 & 90 & 1.94 & 2.14 & 2.04 & On-farm rhizomes, standard \\
\hline
\end{tabular}

${ }^{a}$ Incidence is number of plants with any symptoms (ratings 1, 2, or 3).

b Severity is mean rating number of plants per block.

${ }^{\mathrm{c}}$ Each letter indicates a separate fernery, and numbers refer to sections, which are specific fields.

d Block refers to a quadrant in which 50 plants were rated. Mean is disease incidence or severity in 100 plants at the indicated site.

e Solarized indicates that plastic was placed over existing ferns and left for several months to heat soil without killing rhizomes. New fronds were then allowed to develop.

${ }^{\mathrm{f}}$ Renovated indicates that all fronds were cut, mulch was added, and existing plants were allowed to develop new fronds.

g Small section in which 100 plants were rated; not feasible to divide section into two blocks. 
and fronds of symptomatic and asymptomatic ferns were collected from several nurseries and subjected to inclusion body visualization, negative staining with electron microscopy, double-stranded (ds) RNA analysis, and genus or family specific polymerase chain reaction (PCR) and reverse transcription (RT)-PCR assays. For each assay, a minimum of eight symptomatic and two asymptomatic plants were tested.

Inclusion body visualization. Samples of fronds were examined for inclusion bodies (1). Epidermal strips and hand-sectioned samples of fronds (for examination of the phloem tissues) were stained with Azure A and Orange-green (with and without heat) and examined for the presence of viral inclusions using a Leica DM 2500 compound light microscope.

Negative staining. Fronds and rhizomes were tested using a standard technique for negative staining (7). Tissue macerated in buffer was placed on a formvar-coated grid for $3 \mathrm{~min}$. The liquid was wicked off, and the grid was allowed to air-dry. Grids were examined for 20 to 30 min each using a transmission electron microscope.

dsRNA analysis. Extraction of dsRNA was performed on rhizome tissues using published procedures (15). The batch method was successful with the fern rhizome tissue, which was a better source for extraction than fronds, since fronds were too mucilaginous to extract.

PCR and RT-PCR. Total nucleic acids were extracted from fern frond and rhizome tissues (5). The nucleic acids were sent to Agdia Inc. (Elkhart, IN) and tested against an array of PCR and RT-PCR assays using primers designed to amplify a wide range of viruses within the different genera, families, or groups. The following broad-spectrum PCR and RT-PCR assays were conducted: TSP BEGOMO, TSP BROMO, TSP CARLA, TSP CARMO, TSP CLOSTERO, TSP DIANTHO, TSP ILAR, TSP POTEX, TSP POTYVIRIDAE, TSP TOBAMO, TSP TOBRA, TSP TOMBUS, TSP TOSPO, TSP TRICO, and TSP TYMO.
Survey of commercial ferneries. In 2005, a survey was conducted to assess the incidence and severity of FDS in Costa Rica. The survey included 22 sites (different production "fields") at 15 ferneries representing seven geographical regions (Table 1). At most sites, the rating scale was used to rate 50 plants in each of two quadrants. At four sites (numbers 16 to 19 in Table 1), a single sample of 100 plants was rated due to the small block size of plants at the sites. Overall, 2,200 plants were individually rated. Plants were selected for rating by walking through every third row in the quadrant, stopping every fifth step, and rating the plant immediately on the right. The youngest fully unfurled frond was rated on each plant. Incidence was calculated as the percentage of plants in the block with any FDS symptoms.
Severity was calculated by recording the mean of the ratings of all plants in the block.

Rating of native ferns in close proximity to commercial ferneries. To help understand the origin of FDS, wild ferns located within $100 \mathrm{~m}$ of commercial ferneries were rated using the 0 to 3 rating system. Immediately surrounding two commercial ferneries were protected refuges where agriculture was not permitted and where native ferns were abundant. At the first refuge, six fern species were predominant, and a total of 456 plants were rated; while at the second refuge, five fern species were predominant, and a total of 326 plants were rated (Table 2). The incidence and percentage of wild ferns with no symptoms were calculated from the rating data.

Table 3. Reduced rhizome size and root mass on ferns with distorted frond symptoms of fern distortion syndrome (FDS) in paired sampling of ferneries

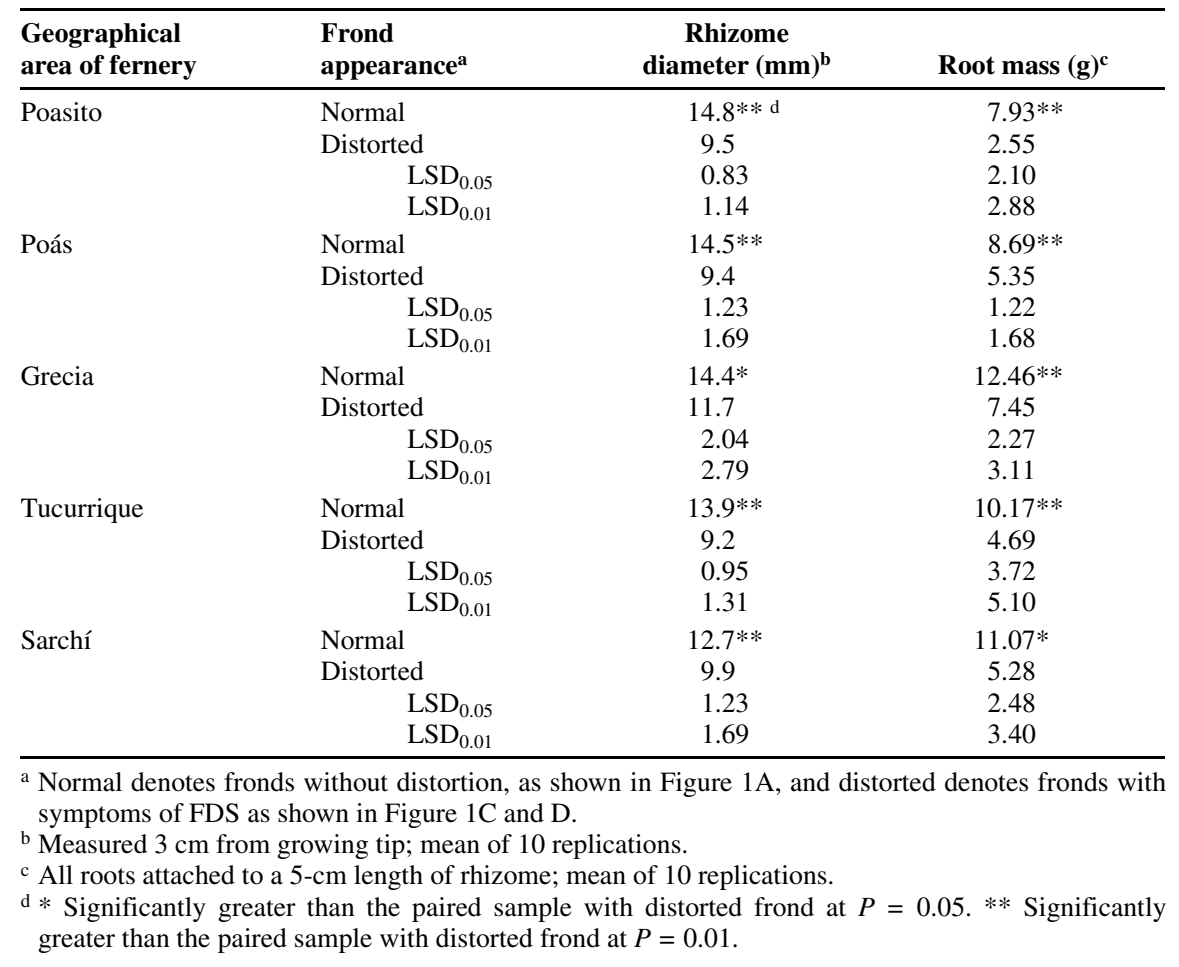

Table 2. Rating of native ferns in refuges within $100 \mathrm{~m}$ of commercial ferneries

\begin{tabular}{|c|c|c|c|c|c|c|}
\hline $\begin{array}{l}\text { Location of } \\
\text { refuge area }\end{array}$ & Species & No. rated & $\begin{array}{l}\text { No. without } \\
\text { symptoms }\end{array}$ & $\begin{array}{l}\text { \% Without } \\
\text { symptoms }\end{array}$ & $\begin{array}{l}\text { No. with } \\
\text { rating of } 1\end{array}$ & $\begin{array}{c}\text { Incidence } \\
(\%)\end{array}$ \\
\hline Guadalupé & $\begin{array}{l}\text { Blechnum occidentale } \\
\text { Lophosoria quadripinnata } \\
\text { Blechnum falciforme } \\
\text { Thelypteris rudis } \\
\text { Pteridium arachnoideum } \\
\text { Adiantum concinnum } \\
\text { Total }\end{array}$ & $\begin{array}{r}67 \\
56 \\
75 \\
130 \\
96 \\
32 \\
456\end{array}$ & $\begin{array}{r}65 \\
55 \\
74 \\
129 \\
94 \\
31 \\
448\end{array}$ & $\begin{array}{l}97 \\
98 \\
98.6 \\
99.2 \\
98 \\
97 \\
98.2\end{array}$ & $\begin{array}{l}2 \\
1 \\
1 \\
1 \\
2 \\
1 \\
8\end{array}$ & $\begin{array}{l}3.0 \\
1.7 \\
1.3 \\
0.8 \\
2.1 \\
3.1 \\
1.8\end{array}$ \\
\hline La Luisa & $\begin{array}{l}\text { Blechnum occidentale } \\
\text { Blechnum falciforme } \\
\text { Richomoanes elegans } \\
\text { Polypodium polypodioides } \\
\text { Dryopteris wallichiana } \\
\text { Total }\end{array}$ & $\begin{array}{r}85 \\
68 \\
36 \\
89 \\
48 \\
326\end{array}$ & $\begin{array}{r}85 \\
68 \\
35 \\
89 \\
48 \\
325\end{array}$ & $\begin{array}{c}100 \\
100 \\
97 \\
100 \\
100 \\
99.7\end{array}$ & $\begin{array}{l}0 \\
0 \\
1 \\
0 \\
0 \\
1\end{array}$ & $\begin{array}{l}0 \\
0 \\
2.8 \\
0 \\
0 \\
0.3\end{array}$ \\
\hline
\end{tabular}

\footnotetext{
a Rating of 0.
} 
Rating of nursery ferns derived from tissue culture and from on-farm rhizomes. As noted above, growers in Costa Rica generally accept that the cause of fern distortions is transmitted to a new production area by the use of rhizomes collected on-farm from mature fields of the farm that have plants with fern distortions. One large commercial fernery (site 15 in Table 1) had its own nursery. In the nursery were large numbers of 5- to 6-month-old ferns grown from rhizomes collected on-farm or from rhizomes that developed from ferns propagated by tissue-culture. A rating was conducted of these two sources in the nursery. In the nursery, ferns are grown from rhizome pieces planted in 10 -cm-diameter plastic bags that are about $30 \mathrm{~cm}$ tall. Ratings were conducted on every plant in each of four blocks (four locations in the nursery) from tissue culture sources and four blocks from on-farm sources. The incidence and severity of FDS were determined for each block, and means for the blocks were analyzed with ANOVA to test for significant differences between the two sources using mean separation at LSD = 0.01 .

Testing the association of endophytic fluorescent pseudomonads with FDS. A protocol was designed to test the hypothesis that distortions of fronds are associated with increased populations of fluorescent pseudomonads inside rhizomes. Isolations were made from rhizomes that were growing fronds with or without FDS symptoms. The rhizomes were collected using the same paired-sampling procedure described above in the section, relation of frond distortion to underground symptoms. From each of six commercial ferneries, 10 replicate rhizomes with symptomatic and asymptomatic fronds were collected. Five of the ferneries were the same used to determine underground symptoms of FDS (Table 3). The sixth fernery was in the Irazú region, which contained nursery growing plants derived from two different sources: vegetative propagation of rhizomes collected in the production beds of the same nursery (on-farm rhizomes) and plants derived from tissue culture stock (the source of locations 16 to 18 in Table 1).

Rhizomes were thoroughly washed in running tap water to remove adherent particles of the growing medium and were then surface-disinfested by soaking for 3 min in $70 \%$ ethanol followed by flaming. After cooling, rhizomes were pressed onto agar plates of $10 \%$ tryptic soy agar $(10 \%$ TSA) to confirm that surface bacteria were eliminated. Sections of rhizomes weighing 2.5 to $3.5 \mathrm{~g}$ were aseptically triturated for 1 min in $10 \mathrm{ml}$ of sterile distilled water (SD

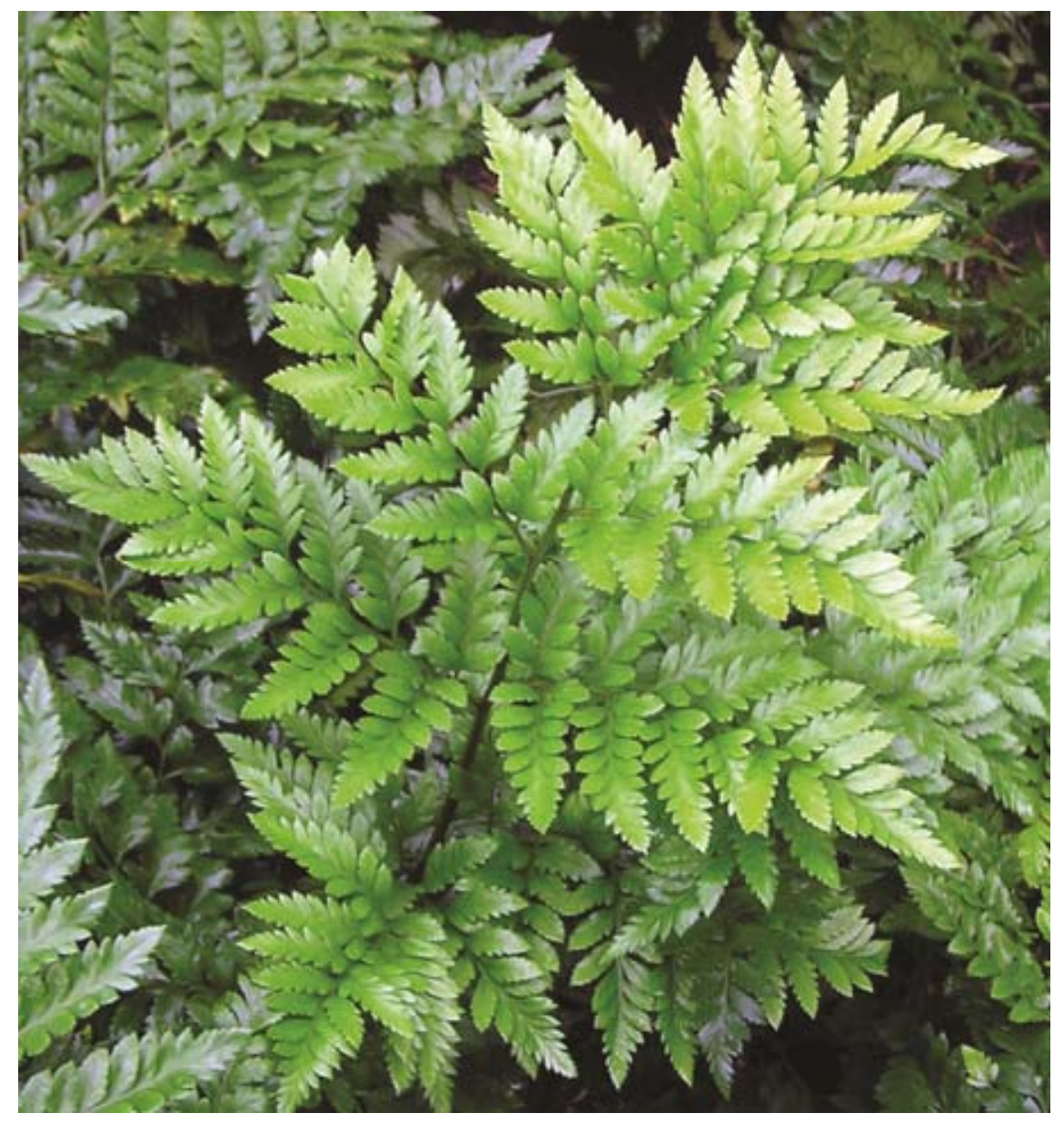

Fig. 2. Growth of pinnae out of the principle plane of frond growth.
$\mathrm{H}_{2} \mathrm{O}$ ) in autoclaved stainless steel ball-mill containers using a Kleco tissue pulverizer (Garcia Manufacturing, Visalia, CA). Serial 10 -fold dilutions to $10^{-3}$ were prepared in $\mathrm{SD} \mathrm{H}_{2} \mathrm{O}$, and $100 \mu$ were plated onto duplicate plates of King's B medium for estimating population densities of fluorescent pseudomonads and onto $10 \%$ TSA for total culturable bacteria. The numbers of fluorescent colonies per plate of King's B medium and of all colonies on $10 \%$ TSA were recorded after incubation at $28^{\circ} \mathrm{C}$ for $48 \mathrm{~h}$. The average number from duplicate plates was used to calculate the log CFU per sample, which was divided by the recorded sample weight to determine mean $\log \mathrm{CFU} / \mathrm{g}$. Hence, from each of the six sample locations, paired sampling was done using 10 replicate rhizomes from symptomatic and asymptomatic ferns. The data from each pair were analyzed by ANOVA using SAS. When a significant $F$ value was determined, LSD values were calculated at $P=0.05$ and 0.01 .

\section{RESULTS}

Description of FDS. Based on reports from growers and from our on-farm observations, we characterize the symptoms of FDS as follows: The most characteristic symptom of FDS is distorted growth of fronds. Healthy-appearing fronds have highly symmetrical growth with the presence of a straight to slightly curving central rachis terminating in a definitive tip (Fig. 1A). With FDS, the symptoms vary from a bending of the tip of newly emerging fronds (Fig. 1B) to a more severe twisting of the rachis, resulting in loss of the symmetrical appearance of the frond (Fig. 1C). Pinnae (the leaf-like segments of a frond) of affected fronds often grow out of the plane of frond growth, resulting in a bunching of growth (Fig. 2). Mature affected fronds may exhibit severely deformed shapes (Fig. 1D). In ferneries with high disease incidence and severity, newly emerging fronds may exhibit more advanced symptoms (Fig. 3), including twisted rachis, loss of a definitive frond tip, and growth of pinnae out of the main frond growth plane.

In addition to the distortions noted above, other symptoms are also sometimes associated with FDS, and these have distinct names in Costa Rica. Brown streaking of pinnae is sometimes termed estriado (striation) (Fig. 4). Red streaking is termed vena roja (red vein) (Fig. 5), while yellow streaking is termed vena amarilla (yellow vein) (Fig. 6) (2). When vena amarilla is severe, especially at higher altitudes with frequent mist or fog, necrosis may also be present, which is termed vena necrótica (Fig. 7) by growers. In areas with high incidence of distortions, as plants age, fronds often become thickened, a condition termed crespera in Costa Rica. When crespera becomes widespread in a fernery, new frond growth ceases or slows dramati- 
cally, and uneven sporulation is often apparent on the underside of fronds (Fig. 8). Each of these symptoms was observed periodically when conducting the rating.

Relation of frond distortion to underground symptoms. Paired sampling of rhizomes connected to fronds with or without distortion symptoms revealed significantly lower rhizome diameter and weight of roots on rhizome sections associated with distortion at all five sampled locations (Table 3). Hence, although frond distortions remain the easiest diagnostic symptom of FDS, reduced rhizome size (Fig. 9A) and root production are also indicated as symptoms. Observations of longitudinal sections of rhizomes revealed the presence of vascular discoloration (Fig.
9B) in 5 of 10 replications from rhizomes giving rise to distorted fronds at Poás and in 8 of 10 at Poasito, while no discoloration was seen in any of the rhizomes giving rise to normally shaped fronds at either location. Fluorescent bacterial colonies were detected on agar plates of King's B medium inoculated by streaking cross-sections of rhizomes with vascular discoloration. Fungi did not grow on water agar or PDA plates streaked in the same manner.

Testing the association of pathogens with FDS. Field isolations for pathogens. Isolations from leaves, rachises, roots, and rhizomes of plants with FDS symptoms failed to detect pathogenic fungi. In a few cases, isolations on nutrient agar detected the presence of Pseudomonas spp.
Electron microscopy. In the samples observed under scanning electron microscopy, the epidermal cells had abundant epicuticular wax, with abundant stomata on the abaxial surface of the pinnae. None of the stomata showed the presence of bacteria or fungi. The vascular bundle showed normal anatomy and absence of bacteria or fungi in xylem and the absence of phytoplasmas in the phloem. Necrosis was observed in the vascular bundles of some roots, but no microorganisms were present.

With transmission electron microscopy, it was possible to observe that nuclei of most spongy mesophyll cells from young pinnae exhibited large nucleoli which were very granulated (Fig. 10A). In the mito-
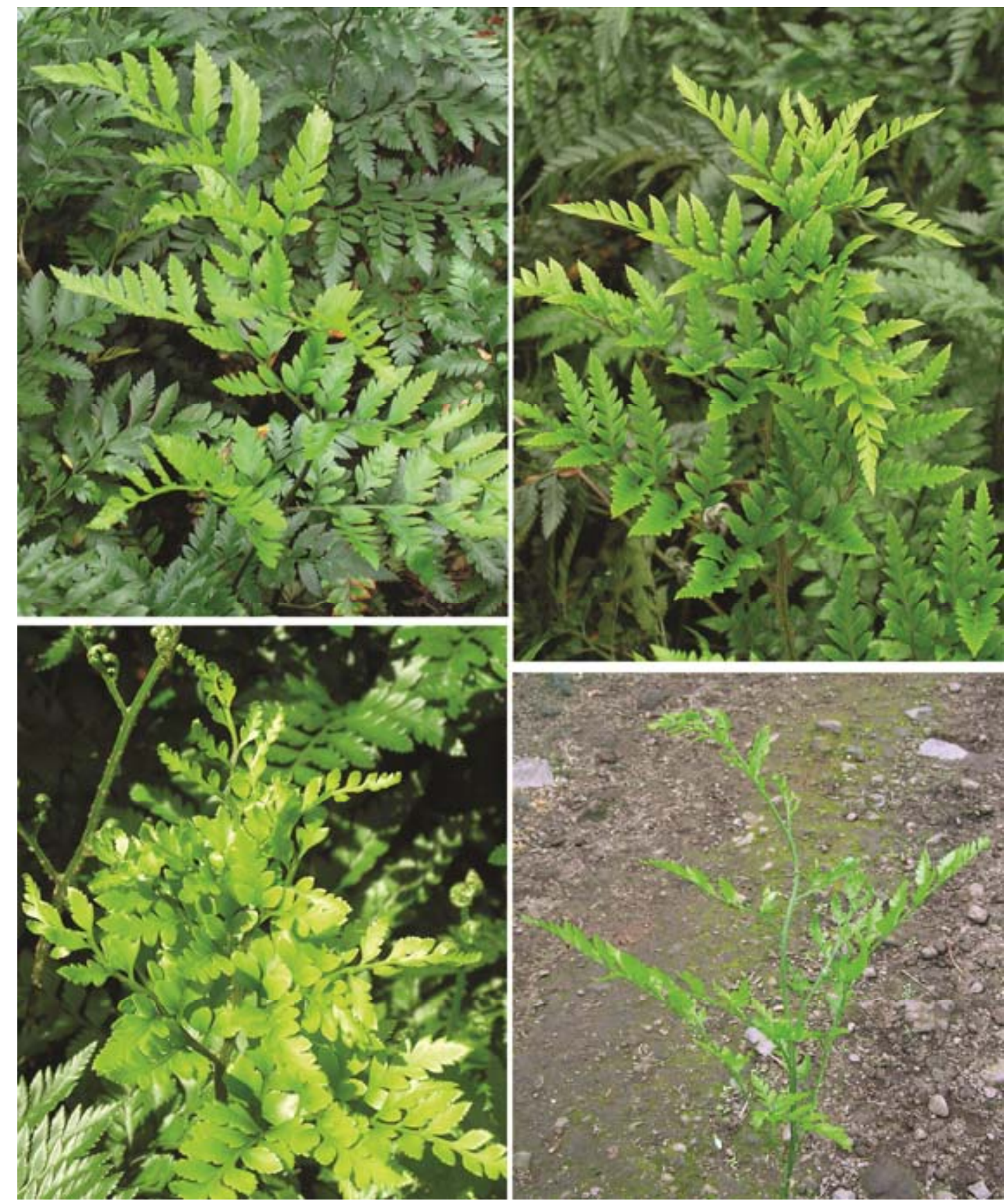

Fig. 3. Advanced stage of deformities in newly emerging fronds. 
chondria of parenchyma and phloem cells, there was breakage and swelling of the cristae. Some chloroplasts of these cells showed contraction of the thylakoids, and in other cases the grana architecture was altered (Fig. 10B and C). Some chloroplasts had plastoglobules (Fig. 10B) and large starch grains, which occupied a high percentage of the chloroplast's volume (Fig. 10D and E).

In the cytoplasm of parenchyma cells of the vascular bundle, the presence of tiny vacuoles containing many fine fibers was notable. In addition, the nucleoli of some cells of the vascular bundle had electron dense crystals. However, these crystals were not part of the symptoms of FDS since they were also present in tissues from asymptomatic control plants. Some cells of the phloem showed vesicle aggregates in the cytoplasm (Fig. 10E). A few of them had very small spherical structures, and in addition the proliferation of membranous system or an apparent swelling of the endoplasmic reticulum was observed (Fig. 10F).

In addition to revealing ultrastructural changes in plant cells, the transmission electron microscopic study revealed the presence of bacteria in many symptomatic plants. A large number of bacteria were observed in different intercellular spaces of the spongy mesophyll of the pinnae (Figs. 10D and 11). Fungi were not detected in any of the electron microscopic analyses.

Detection of plant viruses. Symptomatic and asymptomatic frond and rhizome tissues were tested with broad-spectrum assays that are used to detect a very wide array of plant viruses. None of the assays were able to show a consistent association between symptomatic plants and the presence of a virus. None of the PCR or RTPCR assays gave a positive result. No inclusions were seen in frond cells of ferns showing FDS. Virus-like flexuous rodshaped particles were seen by negative staining in one sample, and in one other sample two dsRNA bands were observed. It is possible that these bands and particles belong to a virus of bacteria, fungi, or plants. There was no consistent association of these with the presence of FDS symptoms, and hence, it is highly unlikely that a plant virus contributes to symptoms of FDS.

Survey of commercial ferneries. Results from the survey of commercial ferneries (Table 1) confirmed that FDS was widespread in Costa Rica. The incidence of distortions was generally greater than $80 \%$, and the mean severity was greater than 1.3. Three sites had a mean incidence of $97 \%$. Each site with lower incidence and severity figures was from sections where changes from standard agronomic practices were made in efforts to ameliorate the severity of FDS. For example, at site number 13, the mean incidence was $78 \%$. During the previous growing season, this site was renovated, a practice that involves cutting off all fronds, adding additional mulch material, and allowing the existing rhizomes to grow new fronds. At site 2 , the mean incidence was $64 \%$ and the mean severity was 0.67 . The previous summer, this site had been solarized, which is the process of covering existing plants with plastic for several months to heat soil without killing the rhizomes. After plastic is removed, the existing rhi-
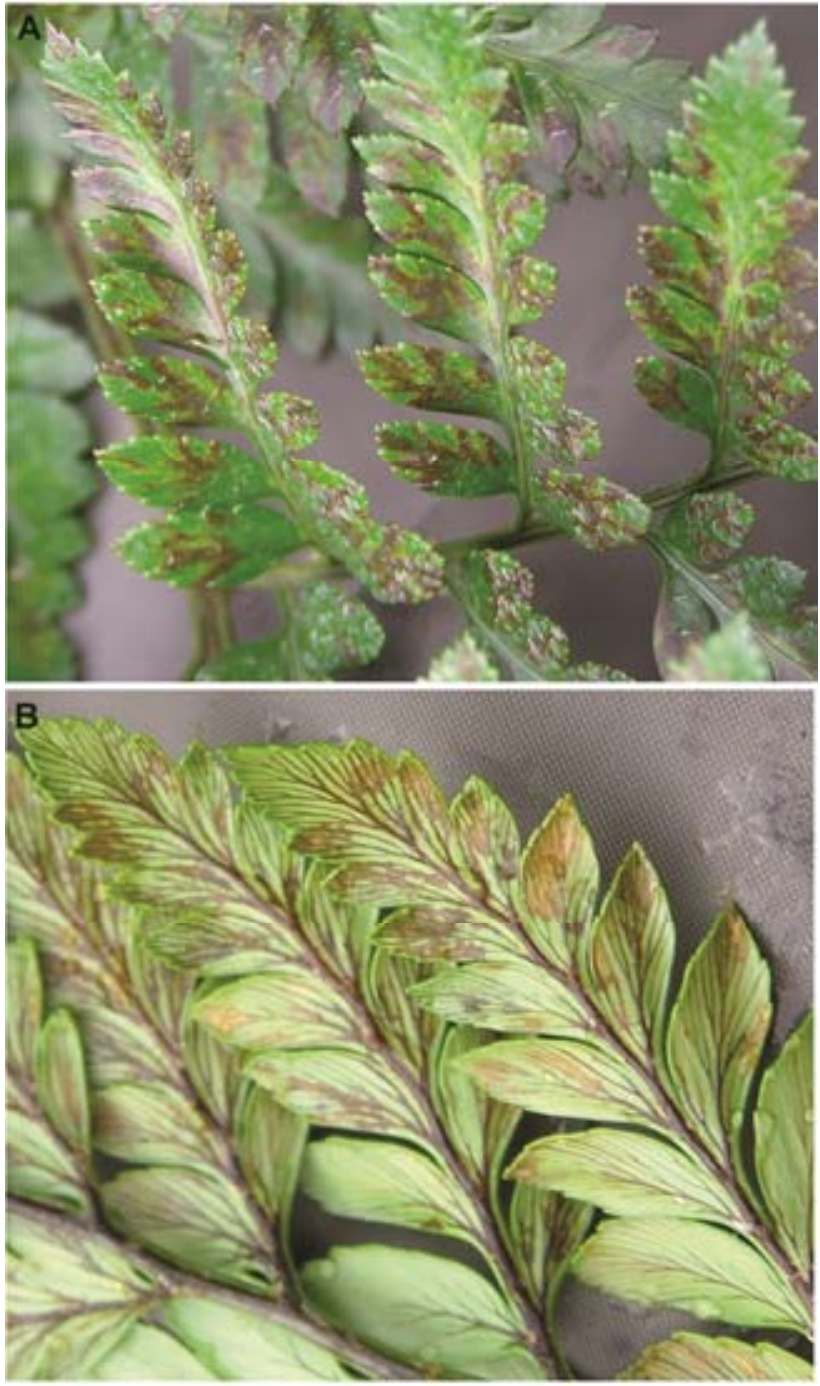

Fig. 4. Estriado (streaking) on $\mathbf{A}$, upper and $\mathbf{B}$, lower surface of frond.

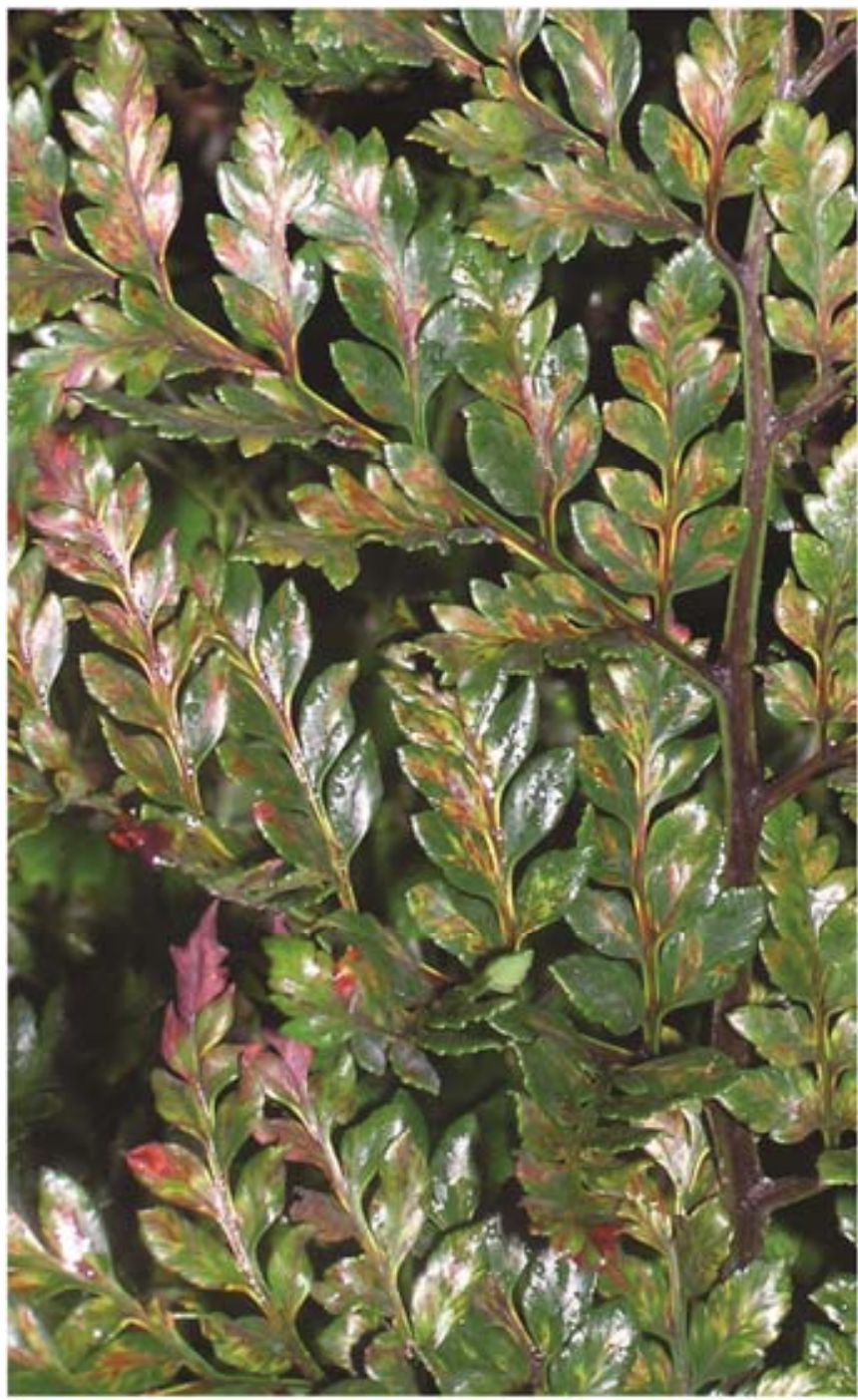

Fig. 5. Fern with vena roja (red vein). 
zomes grow new fronds. The lowest mean incidence figures of 23,25 , and $34 \%$ and the lowest severity ratings of $0.24,0.25$, and 0.36 were found at sites 16,18 , and 17, respectively. All three sites were planted using tissue-culture-derived plants.

Rating of native ferns in close proximity to commercial ferneries. At both of the refuge areas near commercial ferneries, native ferns were mainly without symptoms of FDS (Table 2). Using the same rating scale as was used in the commercial ferneries, the maximum rating detected among native ferns was a rating of 1 . Across both refuges, 773 of 782 ferns had no symptoms (rating of 0 ), and 9 had a rating of 1 . Hence, the overall incidence across both refuges was $1.1 \%$.

Rating of nursery ferns derived from tissue culture and from on-farm rhizomes. The rating of 5- to 6-month-old ferns in the nursery of a commercial fernery revealed that ferns grown from rhizomes collected on the farm had a significantly greater incidence and severity of FDS than did ferns grown from rhizomes derived from tissue culture (Table 4). The mean incidence of FDS across four blocks for on-farm rhizomes was $54 \%$ compared with $1.8 \%$ for ferns derived from tissue culture. The mean severities were 0.70 and 0.02 for ferns derived from on-farm and tissue culture sources, respectively.
Testing the association of endophytic fluorescent pseudomonads with FDS. Significantly greater populations of endophytic fluorescent pseudomonads were detected inside rhizomes of fern plants with distorted fronds than of plants with normal-appearing fronds at all six sampled ferneries (Table 5), and these increases were significant at $P=0.01$. Populations of total culturable bacteria were significantly greater from symptomatic plants at five of the six locations.

\section{DISCUSSION}

This study constitutes the first published description and survey of FDS. Using the 0 to 3 rating scale, FDS was found to be common throughout the various regions of Costa Rica where leatherleaf fern is grown. When developing the rating scale, two main issues needed to be addressed. The first was how many different symptoms to include in the scale. As noted above, ferns that have distortions also sometimes have other symptoms that have been given names, such as vena necrótica, vena roja, estriado, crespera, and vena amarilla. Some of the head agronomists of ferneries in Costa Rica consider these other symptoms to be part of a single disease syndrome, while others consider them to represent a second or even third disease. Given that there are no refereed publica-

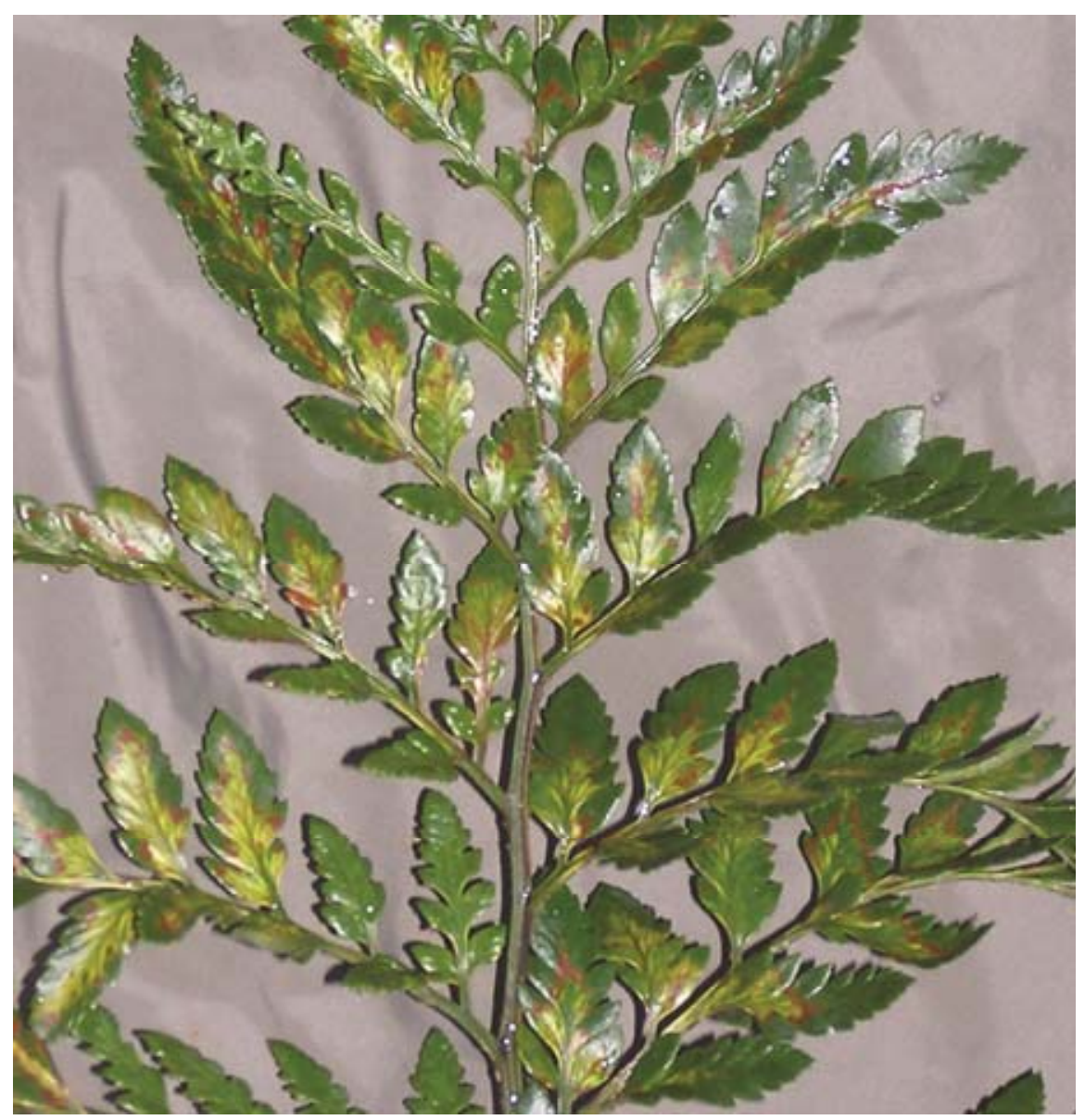

Fig. 6. Fern with vena amarilla (yellow vein). tions describing or rating these other symptoms, we chose to base the rating scale on the level of frond distortion. The second issue related to the rating scale was the question of how many categories or points on the scale to include. After consultation with the head agronomists at several ferneries, we chose the 0 to 3 scale for two reasons. The scale reflects the actual economic losses incurred by ferneries from FDS. According to the head agronomists, fronds that receive a rating of 1 on the scale would still be marketable if they were mixed with fronds without symptoms, but even then, bundles containing some fronds with a rating of 1 would receive a discounted price. Fronds with ratings of 2 or 3 would not be marketable and would be discarded as culls. Another reason for selecting a rating scale with only four categories was that the scale can quickly be taught to others, resulting in more reliable ratings than with a more complicated rating scale.

By tracing distorted fronds down to the rhizome from which they originated, it was determined that the aboveground distortions were related to reduced rhizome size and to reduced root development on the affected rhizome (Table 3). This supports the assertion of many head agronomists in
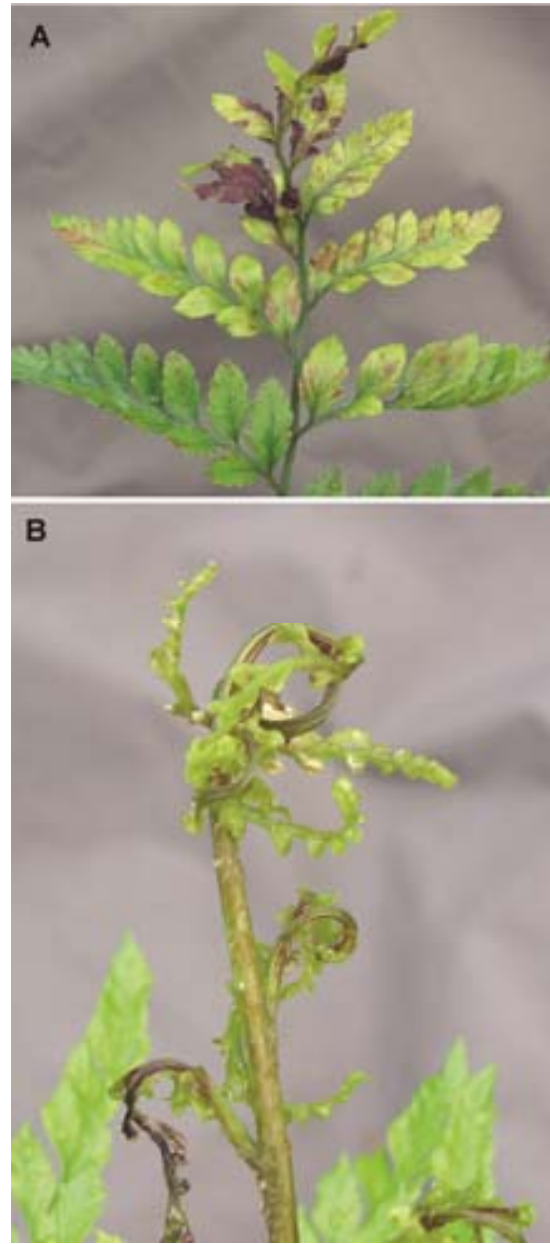

Fig. 7. Vena necrótica on $\mathbf{A}$, young frond and $\mathbf{B}$, crozier. 
commercial ferneries in Costa Rica that reduction of rhizome size is a symptom of the same fern decline problem. In addition, while collecting rhizome samples to measure diameter, we noted that vascular discoloration was evident in some rhizomes that gave rise to distorted fronds (Fig. 9B), while no discoloration was evident in rhizomes giving rise to fronds without distortions. In this case, isolations from discolored rhizomes revealed the presence of up to two log-fold higher levels of fluorescent pseudomonads compared with those from asymptomatic rhizomes.

As noted in the introduction, many unpublished investigations over the years have been conducted in Costa Rica in attempts to find a common pathogen or a common treatment method, such as a chemical spray, to manage FDS. These efforts have failed to find an underlying cause for the syndrome, which is why the results were not published. Results of the efforts reported here to find pathogens using isolations and electron microscopy from pinnae, rachises, rhizomes, and roots of symptomatic plants were similar to the past studies. No fungal, bacterial, phytoplasmal, or viral pathogens were able to be associated with symptomatic plants. However increased populations of endophytic fluorescent pseudomonads were associated with symptoms of FDS.

The finding that $98.9 \%$ of native ferns had no symptoms of FDS (Table 2), even though they were within $100 \mathrm{~m}$ of two commercial ferneries that had a high incidence, suggests that the disease is not transmitted by insect vectors and that aerial transmission does not occur. However,

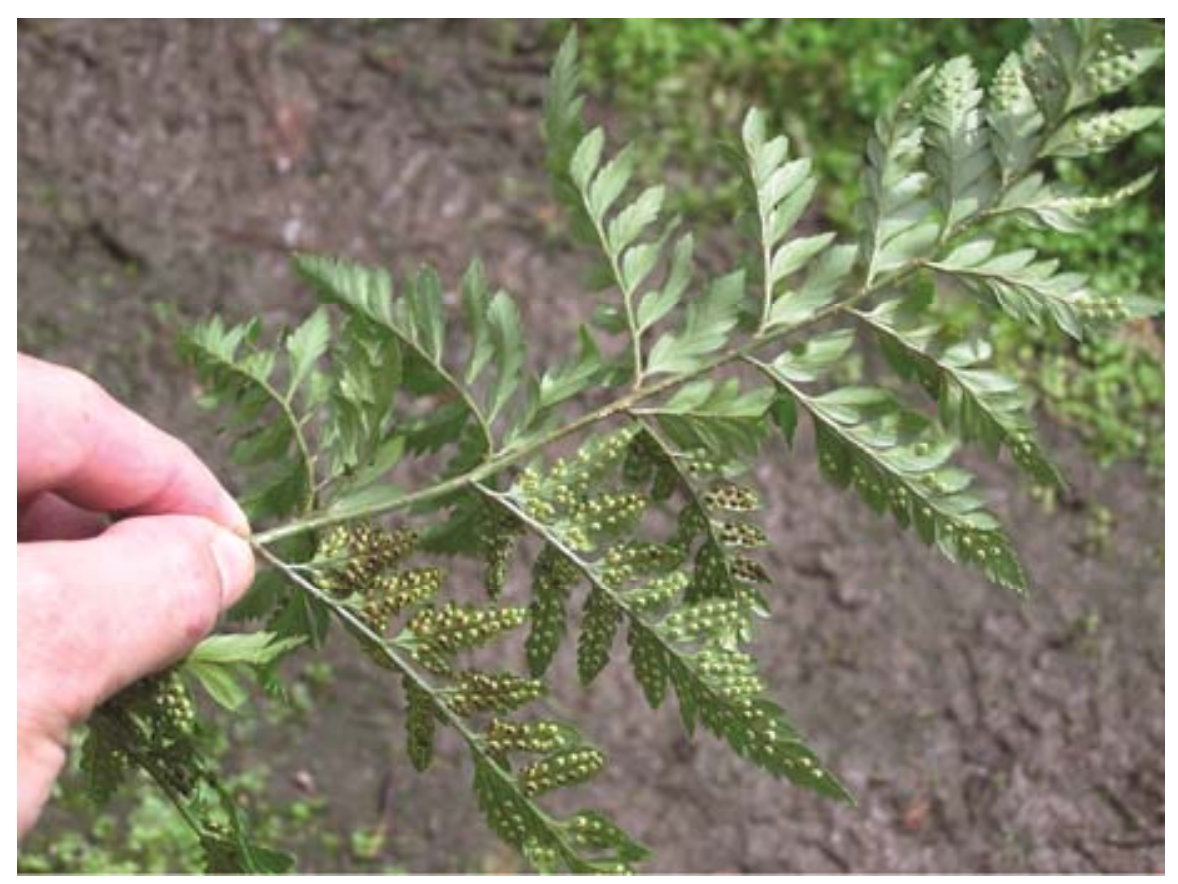

Fig. 8. Uneven pattern and maturity of spores in fernery with a high incidence of fern distortion syndrome. because the native ferns are different species than leatherleaf fern, one could posit that aerial or vector transmission could still be involved specifically for leatherleaf fern. Evidence against aerial transmission also comes from the very low ratings detected in the nursery plants (Table 4), which were located within the commercial ferneries growing mature plants.

Similar distortions of leatherleaf fern as we report here in Costa Rica were noted in Florida, where the distortions were linked to reduced frond production (10). The appearance of increased frond distortions in Florida was reported to coincide with the widespread use of the systemic fungicide Benlate DF (10), which was also reported to promote phytotoxic bacteria in the rhizosphere of leatherleaf fern (9). In one study, compared to controls, ferns treated with Benlate exhibited reduced frond production and root hair formation (10). In the same study, assaying rhizosphere bacteria for allelopathic effects in a lettuce seedling bioassay revealed that $80 \%$ of fluorescent pseudomonads from the ferns treated with Benlate were allelopathic, compared with $6 \%$ of the pseudomonads from the control ferns. From these two studies $(9,10)$, it was suggested that the damage on leatherleaf fern resulted from rhizosphere communities of allelopathic bacteria that were developed following application of Benlate. It is possible that the same disease is in Florida and that in fact the origin of FDS in Costa Rica was from affected rhizomes imported from Florida when the Costa Rican leatherleaf fern industry was started. Import regulations required that rhizomes imported into Costa Rica be drench-treated with Benlate in the mid-1990s (H. A. Mills, personal communication). If communities of allelopathic bacteria developed inside rhizomes of Benlate-treated ferns in Costa Rica as they did in the rhizosphere in the studies in Florida $(9,10)$, this would provide an explanation for the results
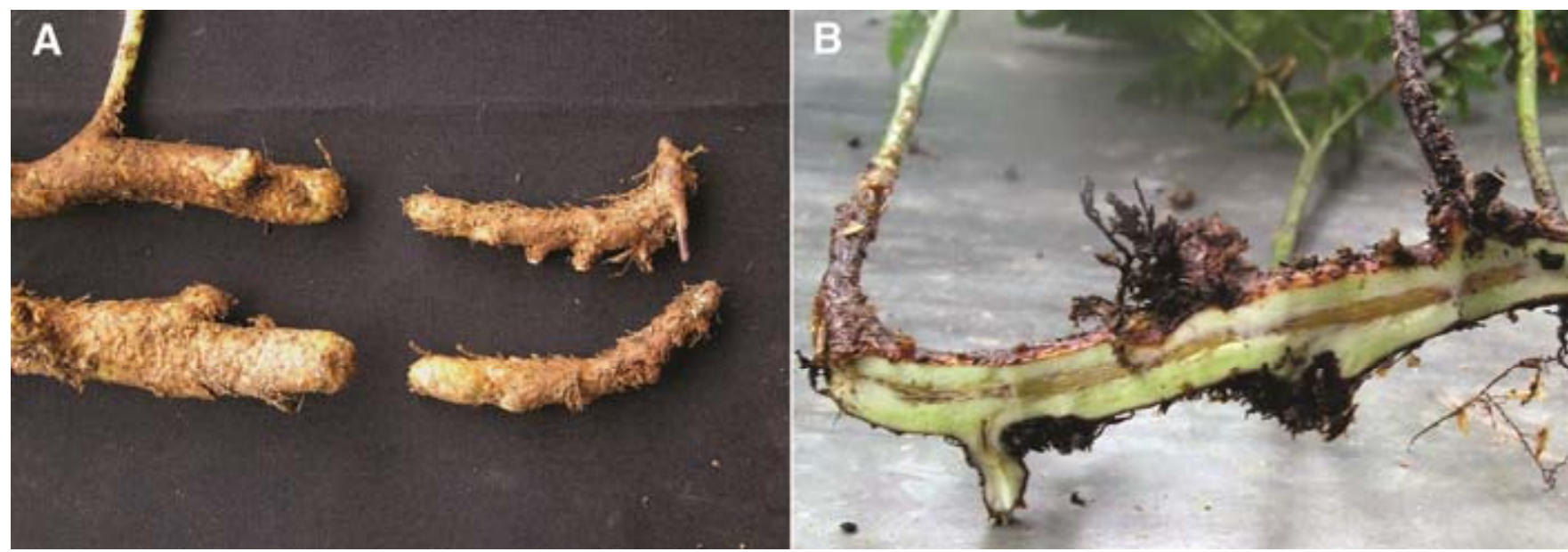

Fig. 9. Symptoms on fern rhizomes. A, Reduced diameter of rhizomes giving rise to fronds with distortion (right) compared with rhizomes giving rise to normal fronds (left). B, Internal discoloration of rhizomes giving rise to distorted fronds. 
presented here suggesting that FDS is transmitted by propagation of infected rhizomes.

The findings reported here that increased populations of endophytic fluorescent pseudomonads are associated with the main FDS symptom of distortion are in agreement with the general suggestion of the Florida work that pseudomonads are related to distortions. The presence of elevated populations of pseudomonads and total culturable endophytic bacteria in rhizomes of symptomatic ferns could help explain observations that FDS is spread by vegetative propagation of rhizomes from diseased fields. Collectively, these results and observations suggest a model of latent infections of allelopathic or deleterious bacteria that induce damage when a threshold population is reached.

Allelopathic bacteria, as reviewed by Barazani and Friedman (1), may evolve in areas where a single crop is grown successively, which is the case with leatherleaf fern in Costa Rica. Allelopathic effects may include reducing or altering normal plant growth through production of allelochemicals, including IAA (1). Barazani and Friedman (1) emphasized that plant damage by allelopathic bacteria is highly dependent on bacterial density and environmental conditions. Owen and Zdor (12) further reported that an endophytic strain of Pseudomonas putida inside roots was allelopathic on velvetleaf (Abutilon theo- phrasti). Our finding that rhizomes of symptomatic leatherleaf ferns contained higher populations of endophytic fluorescent pseudomonads agrees with the concepts of plant damage from allelopathic bacteria. Future work is needed to characterize the isolated pseudomonads for IAA production and allelopathic effects in bioassays used in other studies on allelopathic bacteria.

The results of the survey where ferns were rated for FDS (Table 1) revealed that the incidence was generally greater than $80 \%$, but there were several important exceptions. The lowest incidence levels of 23,34 , and $25 \%$ occurred in sections planted with rhizomes derived from tissue culture. These three sections also had the
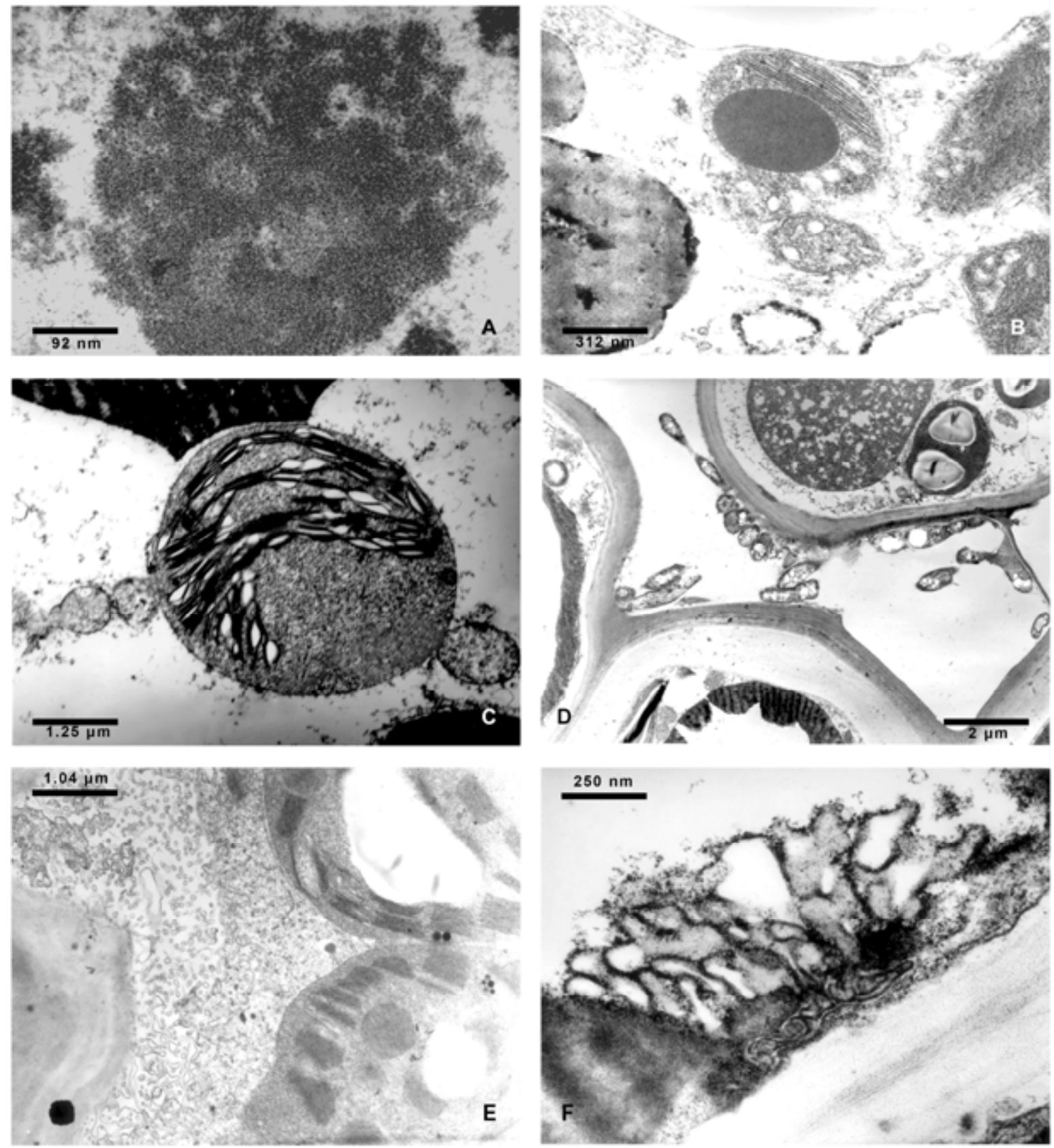

Fig. 10. Ultrastructural changes of pinnae tissues of symptomatic fern plants. A, Granular nucleolus. B, Plastid with altered thylakoids and a large osmiophilic globule. A mitochondria with swollen thylakoids. C, Plastid (chloroplast) with altered thylakoids. D, Spongy mesophyll cells with chloroplasts have big starch granules. Note the abundance of bacteria in intercellular spaces. E, Highly vacuolated cytoplasm. F, Apparent swelling of the endoplasmic reticulum. 

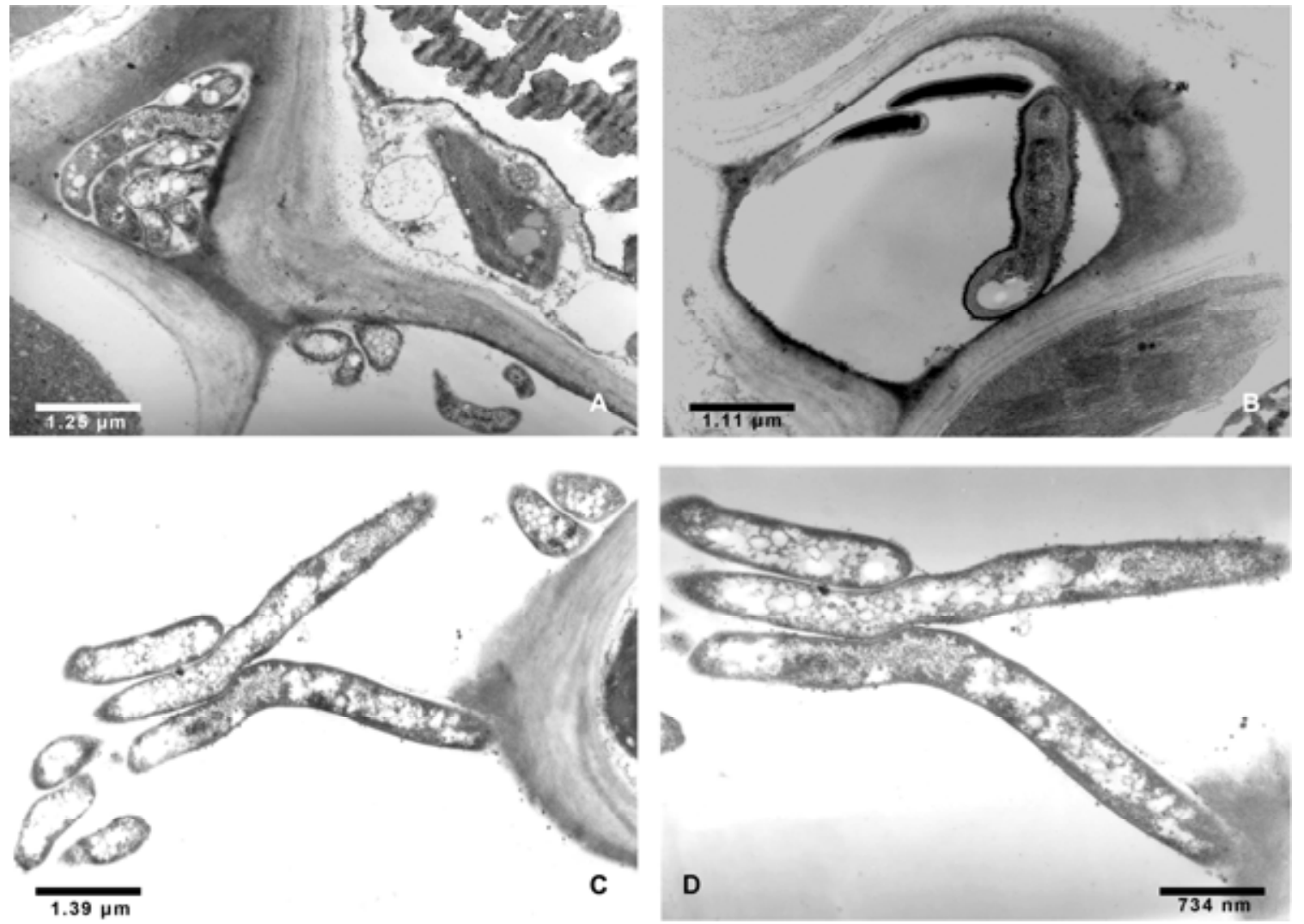

Fig. 11. Bacteria in several intercellular spaces of the spongy mesophyll of the plant pinnae. A, Intercellular spaces of young pinnae showing some bacteria. B, Intercellular spaces of adult pinnae showing a few bacteria. C, Spongy mesophyll intercellular spaces of the other adult pinnae showing some bacteria. D, Higher magnification of some bacteria from C.

Table 4. Rating of nursery ferns derived from on-farm rhizomes or tissue culture

\begin{tabular}{|c|c|c|c|c|c|c|c|}
\hline \multirow[b]{2}{*}{ Origin of plants } & \multirow[b]{2}{*}{ Block number } & \multirow[b]{2}{*}{ Plants in block } & \multicolumn{3}{|c|}{ No. of plants in block with a rating of } & \multirow[b]{2}{*}{ Incidence $(\%)^{\mathbf{a}}$} & \multirow[b]{2}{*}{ Severity } \\
\hline & & & $\mathbf{0}$ & 1 & 2 & & \\
\hline \multirow[t]{5}{*}{ Tissue culture } & 1 & 76 & 75 & 1 & 0 & 1.3 & 0.01 \\
\hline & 2 & 50 & 49 & 1 & 0 & 2.0 & 0.02 \\
\hline & 3 & 65 & 63 & 2 & 0 & 3.1 & 0.03 \\
\hline & 4 & 43 & 42 & 1 & 0 & 2.4 & 0.02 \\
\hline & & & & & Mean & 1.8 & 0.02 \\
\hline \multirow[t]{6}{*}{ On-farm rhizomes } & 1 & 27 & 7 & 17 & 3 & 63 & 0.83 \\
\hline & 2 & 48 & 21 & 19 & 8 & 56 & 0.73 \\
\hline & 3 & 58 & 27 & 26 & 5 & 53 & 0.62 \\
\hline & 4 & 48 & 27 & 13 & 8 & 44 & 0.60 \\
\hline & & & & & Mean & 54 & 0.70 \\
\hline & & & & & $\mathrm{LSD}_{0.01}$ & 14.7 & 0.20 \\
\hline
\end{tabular}

a Incidence is number of plants with any symptoms (ratings 1, 2, or 3).

${ }^{\mathrm{b}}$ Severity is mean rating number of plants per block.

lowest mean severity figures of 0.24 to 0.36. All other sections and locations that had much greater incidence and severity figures grew ferns from on-farm rhizomes. This process involves digging rhizomes from a mature section, cutting the rhizomes into pieces, and planting these pieces in bags or a temporary in-ground nursery containing a large layer of organic mulch. The resulting plants are then transplanted to establish a new section of fern. The low incidence of FDS on ferns grown from rhizomes derived from tissue culture compared with the high incidence on ferns grown from rhizomes suggests that FDS is transmitted through standard vegetative propagation of infected rhizomes carrying soil. Tissue culture is a form of micropropagation and, therefore, a form of vegetative propagation; however, micropropagation removes soil attached to rhizomes and uses only the rhizome tips, which contain fewer endophytic microorganisms.

Further evidence supporting the model that latent infections of rhizomes lead to FDS comes from two other observations. First, at site 2 (Table 1), a form of solarization was practiced the previous year. The incidence and severity (64\% and 0.67 , respectively) were lower than the incidence and severity (97\% and 2.24) for the neighboring section in the same fernery that had not been solarized (site 3 ). The solarization was done by covering existing plants with plastic for several months to heat soil and kill soil pathogens without killing the rhizomes. Second, a paired rating at nursery site 15 (Table 1) between ferns derived from on-farm rhizomes and those derived from tissue culture revealed a mean incidence of over $50 \%$ for ferns from on-farm rhizomes, compared to less than $2 \%$ for ferns from rhizomes derived from tissue culture (Table 4). The finding that distorted fronds were developed in the nursery from rhizomes collected in ferneries with FDS agrees with the observation 
Table 5. Association of fluorescent pseudomonads inside rhizomes with fern distortion syndrome (FDS) symptoms

\begin{tabular}{|c|c|c|c|}
\hline $\begin{array}{l}\text { Geographical } \\
\text { area of fernery }\end{array}$ & $\begin{array}{l}\text { Frond } \\
\text { appearance }\end{array}$ & $\begin{array}{c}\text { Mean } \log \mathrm{CFU} / \mathrm{g} \text { of total } \\
\text { endophytic bacteria }{ }^{\mathrm{b}}\end{array}$ & $\begin{array}{c}\text { Mean } \log \text { CFU/g of } \\
\text { fluorescent pseudomonads }\end{array}$ \\
\hline Poasito & $\begin{array}{l}\text { Normal } \\
\text { Distorted } \\
\quad \operatorname{LSD}_{0.05} \\
\quad \operatorname{LSD}_{0.01}\end{array}$ & $\begin{array}{l}3.28 \\
4.66^{* * d} \\
0.50 \\
0.68\end{array}$ & $\begin{array}{l}0.49 \\
2.50^{* * *} \\
0.62 \\
0.86\end{array}$ \\
\hline Poás & $\begin{array}{l}\text { Normal } \\
\text { Distorted } \\
\quad \operatorname{LSD}_{0.05} \\
\quad \operatorname{LSD}_{0.01}\end{array}$ & $\begin{array}{l}3.64 \\
5.56^{* *} \\
0.45 \\
0.61\end{array}$ & $\begin{array}{l}1.03 \\
3.03 * * \\
1.23 \\
0.09\end{array}$ \\
\hline Grecia & $\begin{array}{l}\text { Normal } \\
\text { Distorted } \\
\quad \operatorname{LSD}_{0.05} \\
\quad \operatorname{LSD}_{0.01}\end{array}$ & $\begin{array}{l}4.35 \\
5.52^{* *} \\
0.26 \\
0.35\end{array}$ & $\begin{array}{l}0.75 \\
2.59 * * \\
0.68 \\
0.93\end{array}$ \\
\hline Tucurrique & $\begin{array}{l}\text { Normal } \\
\text { Distorted } \\
\quad \operatorname{LSD}_{0.05} \\
\quad \operatorname{LSD}_{0.01}\end{array}$ & $\begin{array}{l}3.65 \\
4.08^{*} \\
0.39 \\
0.53\end{array}$ & $\begin{array}{l}0 \\
1.14 * * \\
0.67 \\
0.92\end{array}$ \\
\hline Sarchí & $\begin{array}{l}\text { Normal } \\
\text { Distorted } \\
\quad \operatorname{LSD}_{0.05} \\
\quad \operatorname{LSD}_{0.01}\end{array}$ & $\begin{array}{l}4.40 \\
5.43 \\
1.13 \\
1.55\end{array}$ & $\begin{array}{l}1.88 \\
3.48^{* *} \\
1.13 \\
1.56\end{array}$ \\
\hline Irazú & $\begin{array}{l}\text { Normal } \\
\text { Distorted } \\
\quad \operatorname{LSD}_{0.05} \\
\quad \operatorname{LSD}_{0.01}\end{array}$ & $\begin{array}{l}4.02 \\
5.37 * * \\
0.30 \\
0.41\end{array}$ & $\begin{array}{l}0.86 \\
2.80 * * \\
0.67 \\
0.92\end{array}$ \\
\hline
\end{tabular}

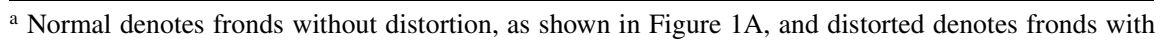
symptoms of FDS as shown in Figure 1C and D.

${ }^{\mathrm{b}}$ Colonies on $10 \%$ tryptic soy agar; mean of 10 replications.

${ }^{c}$ Colonies on King's B medium; mean of 10 replications.

$\mathrm{d} *$ Significantly greater than the paired sample with normal frond at $P=0.05$. ** Significantly greater than the paired sample with normal frond at $P=0.01$.

at location 13 (Table 1). At this site during the previous year, all fronds had been removed and new fronds were allowed to grow as part of an attempt to reduce the incidence of distorted fronds. The observed incidence of $78 \%$ clearly indicates that removing infected fronds does not eliminate the occurrence of distortions; although there may be a temporary reduction in levels of damage considering that most other sites had higher incidence and severity figures. These results do not eliminate the possibility that a soilborne or rhizosphere phase of the allelopathic bacteria could contribute to FDS. Given that natural openings exist at the growing tip of rhizomes, there is likely an exchange of endophytic and rhizosphere bacteria, whereby some allelopathic bacteria residing inside rhizomes could gain entry to the rhizosphere and contribute to contamination of new ferns planted into the same planting bed.

Future work is planned to inoculate healthy leatherleaf ferns with various mixtures of strains of fluorescent pseudomonads isolated from rhizomes of plants with FDS symptoms to determine if the main symptom of deformity is reproduced. Another important area for future investigations is to determine if symptoms other than distortions, such as vena amarilla, vena necrótica, vena roja, estriado, and crespera, are symptoms of FDS. It is possible that there is more than one disease of leatherleaf fern accounting for the various symptoms. Alternatively, these symptoms could also be associated with allelopathic fluorescent pseudomonads, and some, such as yellowing (vena amarilla), streaking of yellow and red (estriado), necrosis (vena necrótica), and red (vena roja), could result from bacterial toxins that are regulated by quorum-sensing and microclimatic factors.

\section{ACKNOWLEDGMENTS}

We thank Mr. Enrique Blair, head of ACOPEHEL (Asociación Costaricense de Productores y Exportadores de Helecho), and all the members for arranging access to ferneries. We also thank the managers and head agronomists of each fernery for advice and descriptions of histories of each fernery. We recognize and thank Alexander Rodríguez for preparing the composite electron microscopic images in Figures 10 and 11. We acknowledge the following sources of financial support for the research presented here: ACOPEHEL, The Alabama Agricultural Experiment Station, Holland and Hart LLP, Centro de Investigación en Estructuras Microscópicas, and Centro de Investigaciones Agronómicas, Universidad de Costa Rica.
LITERATURE CITED

1. Barazani, O., and Friedman, J. 2001. Allelopathic bacteria and their impact on higher plants. Crit. Rev. Microbiol. 27:41-55.

2. Christie, R. G., and Edwardson, J. R. 1986. Light microscopic techniques for detection of plant virus inclusions. Plant Dis. 70: 273279.

3. Clark, M. A. 1995. Nontraditional export promotion in Costa Rica: Sustaining export-led growth. J. Interam. Stud. World Affairs 37:181-223.

4. Dominguez, L. D. 1996. Producción de follajes para la exportación. X Congreso Nacional Agronómico. Published online. http://orton. catie.ac.cr/cgi-bin/wxis.exe/?IsisScript $=\mathrm{CNP}$ xis\&method $=$ post $\&$ formato $=2 \&$ cantidad $=$ 1 \&expresion $=\mathrm{mfn}=002233$

5. Doyle, J. J., and Doyle, J. L. 1987. A rapid isolation procedure for small quantities of fresh leaf tissue. Phytochem. Bull. 19:11-15.

6. Gil-Sares, G. J. 2003. Sistema integral para el manejo de nutrición en las plantaciones de helecho hoja de cuero (Rumorha adiantiformis) en Costa Rica. Published online. http://usi. earth.ac.cr/glas/sp/dpg/2000039.pdf

7. Griffin, R. L. 1990. Using the transmission electron microscope in the biological sciences. Ellis Horwood, New York.

8. Kloepper, J. W., Mills, H. A., Saborío, F., and Bustamante, E. 2007. Fern distortion syndrome: A newly described disease of Leatherleaf fern. (Abstr.) Phytopathology 97:S181182.

9. Kremer, R. J., Sasseville, D. N., and Mills, H A. 1996. Promotion of phytotoxic bacteria in rhizospheres of leatherleaf fern by Benlate DF. J. Plant Nutr. 19:939-953.

10. Mills, H. A., Sasseville, D. N., and Kremer, R. J. 1996. Effects of Benlate on leatherleaf fern growth, root morphology and rhizosphere bacteria. J. Plant Nutr. 19:917-937.

11. Mo-Lee, C. 2001. Environmental impact of leatherleaf fern farms in Costa Rica. Ph.D. diss. University of Wisconsin, Madison, WI.

12. Owen, A., and Zdor, R. 2001. Effect of cyanogenic rhizobacteria on the growth of velvetleaf (Abutilon theophrasti) and corn (Zea mays) in autoclaved soil and the influence of supplemental gylcine. Soil Biol. Biochem. 33:801809.

13. Stamps, R. H. 1992. Commercial leatherleaf fern culture in the United States of America. Pages 243-249 in: Fern Horticulture: Past, Present and Future Perspectives. J. M. Ide, A. C. Jermy, and A. M. Paul, eds. Intercept, Andover, UK.

14. Torres-Tamayo, J. F. 1998. Análisis del mercado internacional de helechos de Costa Rica en Europa. Ministerio de Agricultura y Ganadería, Costa Rica. Published online. http://orton.catie.ac.cr/cgi-bin/wxis.exe/?Isis Script=TESISUM .xis\&method=post $\&$ formato $=2 \&$ cantidad $=1$ \&expresion $=m f n=000980$

15. Valverde, R. A., Nameth, S. T., and Jordan, R. L. 1990. Analysis of double-stranded RNAfor plant virus diagnosis. Plant Dis. 74:255-258.

16. Vargas-González, E. 1998. Manejo de la salud de la raíz y la nutrición para el combate de enfermedades en plantas. Seminario Agrícola Internacional. I, San José, Costa Rica, 22-23 de abril de 1998. Published online. http://orton. catie.ac.cr/cgi-bin/wxis.exe/?IsisScript=OET. xis\&method $=$ post $\&$ formato $=2 \&$ cantidad $=1 \&$ expresion $=\mathrm{mfn}=015567$ 